\title{
Response of Mungbean Yield and Yield Components into Various Levels of Phosphorous
}

\author{
Junaid Ahmad*, Farhan Ahmad, Sarmad Iqbal, Basit Ali, Syed Minhaj Ali Shah, Mehran Ali, Haqnawaz, \\ Muhammad Waseem Abbas and Zahid Mehmood
}

Department of Agronomy, Faculty of Crop Production Sciences, The University of Agriculture, Peshawar-Pakistan

Submitted: August 25, 2018; Published: September 11, 2018

*Corresponding author: Junaid Ahmad, Department of Agronomy, Faculty of Crop Production Sciences, The University of Agriculture, PeshawarPakistan, Email: Junaid.agri@aup.edu.pk

\begin{abstract}
This study was aimed to help the farmers to decide the optimum dose of phosphorous fertilizer whether they can use the recommended dose for achieving higher yield of mungbean in agro climatic condition of Peshawar. Farmers need to know what fertilizer application rate they should use under their conditions for adequate productivity. To obtain these objectives an experiment was carried out at Agricultural Research Farm Agricultural University Peshawar during 2017. Five levels of P i.e. 0, 20, 40, 60 and $80 \mathrm{~kg}^{-1}$ on mung bean were studied in the experiment. Mungbean cultivar NM-92 was sown in the experiment. Phosphorus application was significant for all the parameters. Plots treated with 60 kg $\mathrm{P} \mathrm{ha}^{-1}$ produced maximum nodules plant $\mathrm{t}^{-1}(25)$, pods plant $\mathrm{t}^{-1}(22)$, seeds pod ${ }^{-1}(11), 1000$ grains weight (40.2 g), biological yield (4595 kg ha $\left.{ }^{-1}\right)$,

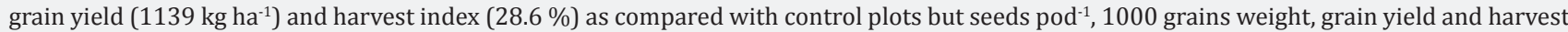
index was statistically at par when plots treated with $80 \mathrm{~kg} \mathrm{P} \mathrm{ha}^{-1}$. Increased in fertilizer has increased these parameters up to some extent and a decreasing trend was observed beyond $40 \mathrm{~kg} \mathrm{ha}^{-1}$ phosphorous application. Regarding yield $80 \%$ variations was accorded by the phosphorous application. Based on the above facts it is concluded that mungbean cultivar NM-92 applied with $60 \mathrm{~kg}^{\mathrm{P}}$ ha-1 was better in terms of yield and yield components and may be recommended for cultivation in agro-climatic condition of Peshawar
\end{abstract}

\section{Introduction}

According to the nutritionists, pulses are an excellent source of dietary proteins and can play an important role in fulfilling requirements of rapidly increasing population. Mungbean (Vigna radiata L.) is an important pulse crop that can be grown twice a year i.e. in spring and autumn. Among the grain legumes, it is one of the important conventional pulse crops of Pakistan [1]. It is highly prised for its rich protein contents $24 \%$ with excellent digestibility as compared with soybean [2]. It ranks second to chickpea (Cicer arietinum) amongst grain legumes from production point of view. Its seed is more palatable, nutritive, digestible and non-flatulent than other pulses grown in country. It contains $24.7 \%$ protein, $0.6 \%$ fat, $0.9 \%$ fiber and $3.7 \%$ ash [3]. In Pakistan mungbean was grown on an area of 137.4 hectare with average production 76.2 tons per hectare during 2015. In Khyber Pakhtunkhwa the mungbean was grown on of 8.5 hectare with average yield $600 \mathrm{~kg} \mathrm{ha}^{-1}[4]$. Besides being a rich source of protein, it maintains soil fertility through biological nitrogen fixation in soil and thus plays a vital role in furthering sustainable agriculture [5]. It is a short duration crop therefore has less water requirement as compared to summer crops. Moreover, it is drought resistant that can withstand adverse environmental conditions, and hence successfully be grown in rain fed areas [6].

Phosphorus (P) is an essential nutrient element for plant growth and development [7]. It is necessary for the formation and translocation of all intermediate end products. Also it plays a major role in stimulating early root growth, thus encourages $\mathrm{P}$ mineralization by plant as well as hastening plant maturity and improving good quality seed [8]. Mungbean is highly responsive to fertilizers and has a considerable response to phosphorus. Phosphorus (P) is frequently one of the most limiting nutrients for plant growth in the tropics, and it is estimated that over $50 \%$ of common bean production in tropical soils is limited by phosphate deficiency [9]. $\mathrm{P}$ is found in all living plant cell and resumes several key plant functions including energy transfer, photosynthesis, transformation of sugars and starches, nutrient movement within the plant [10]. The present study was therefore, undertaken to find out the optimum phosphorus levels required for obtaining high yield of mungbean under conditions prevailing in Peshawar.

\section{Materials and Methods}

The experiment entitled with Response of mungbean yield and yield components into various levels of phosphorous was carried out at New Developmental Farm of The University of Agriculture, Peshawar (34o 00' N, 71o 30' E, 510 MASL) Pakistan during summer 2017. The experiment was laid out in randomized complete block design and replicated thrice. five levels of phosphorus $\left(0,20,40,60\right.$ and $\left.80 \mathrm{~kg} \mathrm{ha}^{-1}\right)$ were used in experiment. Basal dose of Nitrogen was applied at $30 \mathrm{~kg} \mathrm{ha}^{-1}$ 
at the time of sowing. SSP and Urea were used as a source of phosphorous and Nitrogen. Mungbean cultivar NM-92 was sown in the experiment. Plot size of $3 \mathrm{~m} \times 3 \mathrm{~m}$ with 10 rows, $30 \mathrm{~cm}$ Row to row and $10 \mathrm{~cm}$ plant to plant distance was maintained respectively. Seeds were sowed in the $2^{\text {nd }}$ week of June at seed rate of $25 \mathrm{~kg} \mathrm{ha}^{-1}$. Agronomic practices were carried out uniformly for all the experimental units throughout the growing season. Nodules plant ${ }^{-1}$ at the time of pod initiation was counted by uprooting five plants randomly in each subplot and then average was worked out. Number of pods plant ${ }^{-1}$ was counted for ten plants selected randomly in each subplot. Seeds pod ${ }^{-1}$ was recorded by counting seed in ten capsules selected randomly in each sub plot. Four central rows in each sub plots were harvested, sun dried and threshed. Seed weight was taken with the help of electronic balance and then converted into $\mathrm{kg} \mathrm{ha}^{-1}$ by the formula of grain and biological yield. All data collected were subjected to

Table 1: LSD (0.05) value of $P$ for Pods plant ${ }^{-1}=0.61$. analysis of variance (ANOVA) with the help of statistical software, Statistix 8.1 USA [11]. Upon significant F-Test, least significance difference (LSD) test was used for mean comparison to identify the significant components of the treatment means.

\section{Results and Discussion}

\section{Number of Nodules Plant ${ }^{-1}$}

Data presented in Table 1 showed that the different levels of phosphorus had significant effect on number of nodules plant $^{-1}$. Mean values of data indicated that plots treated with 60 kg P ha-1 produced maximum number of nodules plant ${ }^{-1}(26)$, while minimum number of nodules plant ${ }^{-1}$ (12) was recorded in control plots. Our results agree with [12] who reported that $\mathrm{P}$ application promotes early root formation and the formation of lateral fibrous and healthy roots, which had positive effect on nodules plant ${ }^{-1}$.

\begin{tabular}{|c|c|c|c|}
\hline \multicolumn{4}{|c|}{ Yield and Yield Components of Mungbean as Affected by Various Phosphorous Levels } \\
\hline \multicolumn{2}{|c|}{ Yield and Yield Components Parameters } \\
\hline P Levels & Nodules & Pods & Seeds pod $^{\mathbf{1}}$ \\
\hline 0 & 12 & 16 & 9 \\
\hline 20 & 16 & 16 & 10 \\
\hline 60 & 21 & 18 & 10 \\
\hline 80 & 26 & 25 & 13 \\
\hline Mean & 23 & 22 & 11 \\
\hline
\end{tabular}

LSD (0.05) value of $P$ for seeds pod $^{-1}=0.87$.

LSD (0.05) value of $P$ for Nodules plant ${ }^{-1}=0.63$.

\section{Number of Pods Plant ${ }^{-1}$}

Various Phosphorus levels on yield components of mungbean had significant effect on number of pods plant ${ }^{-1}$. Mean values of data presenting in Table 1 showed that plots treated with $60 \mathrm{~kg}$ $\mathrm{P} \mathrm{ha}^{-1}$ produced maximum number of pods plant ${ }^{-1}(25)$, while minimum number of pods plant ${ }^{-1}(16)$ were recorded in control plots. These results agree with [13] who reported that $P$ induced significant increase in pods plant ${ }^{-1}[14]$. Who also reported that phosphorus up to $65 \mathrm{~kg} \mathrm{ha}^{-1}$ significantly increase number of pod plant ${ }^{-1}$.

\section{Number of Seeds pod po $^{-1}$}

Statistical analysis of the data revealed that phosphorus levels had significant effect on number of grains $\operatorname{pod}^{-1}$. Data presenting in Table 1 showed that Grains pod $^{-1}$ was increased with increase in phosphorus levels. Mean value of the phosphorus level indicated that plot treated with 60 or $80 \mathrm{~kg}$ $\mathrm{P} \mathrm{ha}^{-1}$ produced maximum grains pod ${ }^{-1}$, while minimum grains $\operatorname{pod}^{-1}(9)$ were recorded in control plots. These results also in line with the results of [15] who reported that significant differences in number of grains pod $^{-1}$ with various $\mathrm{P}$ levels.

\section{Thousand Grains Weight (g)}

Statistical analysis of the data showed that phosphorus levels had significant effect on thousands seed weight. Data showed in Table 2 revealed that Plots treated with $60 \mathrm{~kg} \mathrm{P} \mathrm{ha}^{-1}$ produced the heaviest grains (39.3 g) being at par with $80 \mathrm{~kg} \mathrm{P} \mathrm{ha}^{-1}$, while lighter grains (33.4 g) was recoded in control plots which is at par with $20 \mathrm{~kg} \mathrm{P} \mathrm{ha}^{-1}$. These results agree with the results of [16] who reported that increasing phosphorus application up to 65 $\mathrm{kg} \mathrm{ha}^{-1}$ significantly increased the seed weight as compared with control plots.

\section{Grain Yield (kg ha-1)}

Grain yield of mungbean was significantly affected by different phosphorous levels. Data presenting in Table 2 shows Mean value of phosphorus levels indicated that plots treated with $60 \mathrm{~kg} \mathrm{P} \mathrm{ha}^{-1}$ produced maximum grain yield (1067 kg ha-1) being at par with $80 \mathrm{~kg} \mathrm{P} \mathrm{ha}^{-1}$, while minimum grain yield $(645$ $\mathrm{kg} \mathrm{ha}^{-1}$ ) was recorded in control plots. These results agree with those of [17] who reported increase of grain yield with increasing the phosphorous levels upto $65 \mathrm{~kg} \mathrm{ha}^{-1}$ further increase in P level slight decrease recorded in grain yield. The increase in grain yield might be due to phosphorus application was performed to more in number of branching, good fruiting, increased number of seeds pod ${ }^{-1}$ and heavier grains as a result grain yield increased as compared with control plots. 
Table 2: $\operatorname{LSD}(0.05)$ value of $P$ for 1000 seed weight $=1.23$

\begin{tabular}{|c|c|c|c|}
\hline \multicolumn{4}{|c|}{ Yield and Yield Components of Mungbean as Affected by Various Phosphorous Levels } \\
\hline \multicolumn{2}{|c|}{ Yield and Yield Components Parameters } \\
\hline P Levels & $\mathbf{1 0 0 0 ~ G W}$ & GY kg ha-1 & \multicolumn{2}{|c|}{ BY kg ha $^{-1}$} \\
\hline 0 & 33.4 & 645 & 2513.45 \\
\hline 20 & 35.2 & 734 & 2784.59 \\
\hline 40 & 36.5 & 852 & 3094.24 \\
\hline 60 & 39.3 & 1067 & 3682.51 \\
\hline 80 & 37.4 & 974 & 3419.93 \\
\hline Mean & 36.36 & 854.4 & 29.5 \\
\hline
\end{tabular}

LSD $(0.05)$ value of $\mathrm{P}$ for Grain yield $\left(\mathrm{kg} \mathrm{ha}^{-1}\right)=29.16$.

$\operatorname{LSD}(0.05)$ value of $\mathrm{P}$ for Biological yield $\left(\mathrm{kg} \mathrm{ha}^{-1}\right)=88.17$.

LSD (0.05) value of $P$ for Harvest index $(\%)=0.98$.

$\mathrm{GW}=$ Grain weight, $\mathrm{GY}=$ Grain Yield, $\mathrm{BY}=$ Biological yield, $\mathrm{HI}=$ Harvest index

\section{Biological Yield}

Biological yield data of mungbean as affected phosphorous application rate are given in Table 2 . Statistical analysis of the data showed that phosphorous application had significantly affected biological yield of the mungbean crop. According to the mean values of the data shows addition of $\mathrm{P}$ fertilizer had increased biological yield from (2513.45 $\mathrm{kg} \mathrm{ha}^{-1}$ ) recorded in control plots to (3682.51 $\mathrm{kg} \mathrm{ha}^{-1}$ ) recorded in plots applied with higher dose of phosphorous i.e. $60 \mathrm{~kg} \mathrm{ha}^{-1}$. The higher dose of fertilizer has probably delayed maturity in crops and improved vegetative growth by providing a balance levels synchronized nitrogen availably. These results are in line with [12] who reported that mungbean growth and total dry matter production was higher in plots treated with P fertilizer (either from organic or inorganic source) as compared to control. Phosphorus fertilizer helps the crop to produce more seed and other reproductive parts that ultimately contributed to total biological yield and other yield components. Our results are confirmed by the findings of [11].

\section{Harvest Index (\%)}

Statistical analysis of harvest index data showed that various levels of phosphorus (P) had significant effect on harvest index. Data presenting in Table 2 shows with the increase of phosphorus level harvest index increasing significantly and plots treated with $60 \mathrm{~kg} \mathrm{P}^{-1}$ produced the maximum harvest index $(29.5 \%)$ being at par with $80 \mathrm{~kg} \mathrm{P} \mathrm{ha}^{-1}$, while minimum harvest index (22.9\%) was recorded in control plots. These results agree with the findings of [17] who reported that increasing rate of phosphorus application significantly increased harvest index over control plots.

\section{Conclusion and Recommendation}

From the results of our experiment it is concluded that for higher yield mungbean should be sown with best phosphorous level $60 \mathrm{~kg} \mathrm{P} \mathrm{ha}^{-1}$ in agro climatic condition of Peshawar. The results obtained from the present research work indicated that cultivar NM-92 treated with $60 \mathrm{~kg} \mathrm{P} \mathrm{ha-1}$ produced maximum nodules plant ${ }^{-1}$, pods plant ${ }^{-1}$, seeds pod $^{-1}, 1000$ grain weight, grain yield, biological yield and harvest index significantly and therefore, it is recommended that cultivar NM-92 should be sown under the Peshawar valley condition with the application of phosphorus $80 \mathrm{~kg} \mathrm{ha}^{-1}$ for higher yield and yield components.

\section{References}

1. Hussain F, AU Malik, MA Haji, AL Malghani (2011) Growth and yield response of two cultivars of mungbean (vign radiata l.) to different potassium levels. The Journal of Animal \& Plant Sciences 21(3): 622-625.

2. Potter NN, JH Hotchkiss (1997) Food Science. CBS Publishers, New Delhi, India pp. 403.

3. Kannaiyan S (1999) Bioresource technology for sustainable agriculture. Associated Publishing Company. New Delhi, India pp. 422.

4. El-Kramany MF, AA Bahr, AM Gomaa (2001) Response of a local and some exotic mungbean varieties to bio- and mineral fertilization. Acta Agronomica Hungarica 49(3): 251-259.

5. Anjum MS, ZI Ahmed, CA Rauf (2006) Effect of Rhizobium Inoculation and Nitrogen Fertilizer on Yield and Yield Components of Mungbean. Int J Agric \& Biol 8(2): 238-240.

6. Bhuiyan MMH, Rahman MM, Afroze F, Sutradhar GNC, Bhuiyan MSI (2008) Effect of Phosphorus, Molybdenum and Rhizobium Inoculation on Growth and Nodulation of Mungbean. J Soil Nature 2(2): 25-30.

7. Khan MB, M Asif, $N$ Hussain, M Aziz (2003) Impact of Different Levels of Phosphorus on Growth and Yield of Mungbean Genotypes. Asian Journal of Plant Sciences 2(9): 677-679.

8. Malik MA, S Hussain, EA Warraich, A Habib, S Ullah (2004) Effect of Seed Inoculation and Phosphorus Application on Growth, Seed Yield and Quality of Mungbean (Vigna radiata L.) CV NM-98. Inter J Agri Bio 515(4): 1560-8530.

9. Naeem M, S Ahmed, ZA Cheema (2000) Yield of Mungbean as Affected by Different Durations of Weed Competition under High Phosphorus Status. Inter J Agric Bio 1560(2): 133-135.

10. Kumar R, YV Singh, S Singh, AM Latare, PK Mishra, et al. (2012) Effect of phosphorus and sulphur nutrition on yield attributes, yield of mungbean (Vigna radiata L. Wilczek). Journal of Chemical and Pharmaceutical Research 4(5): 2571-2573.

11. Ali A, MA Choudhry, A Tanveer (2000) Response of Mungbean (Vigna radiata) genotype to rhizobia culture. Pak J Agri Sci 37(1-2).

12. Sarwar G, MS Sadiq, M Saleem, G Abbas (2004) Selection criteria in F3 and F4 population of mungbean Vigna radiata L. Wilczek. Pak J Bot 36(2): 297-310.

13. MINFAL (2015) Agriculture statistic of Pakistan, Ministry of food, agriculture and Livestock Govt. of Pakistan, Islamabad. 
14. Mehdi SM, O Rehman, M Sartraz, B Ahmad, S Afrsal (2010) Residual effect of wheat applied phosphorus on sorghum Fodder in a sandy soil. Pakistan J Sc 62(4): 202-206.

15. Abdullahi A, EO Uyovbisere (2011) Nitrogen and Phosphorus Requirements of NERICA Rice varieties in a savanna Alfisol. Nigeria J soil and environmental Research 9: 20-28.

16. Khurana A, Sharma P (2000) Effect of Dual Inoculation of Phosphate Solubilizing Bacteria, Bradyrhizobium sp. (cicer) and Phosphorus on
Nitrogen Fixation and Yield of Chickpea. Indian Journal of Pulses Research 13: 66-67.

17. Uchida R (2000) Essential Nutrients for Plant Growth: Nutrient Functions and Deficiency Symptoms. In Silva JA, Uchida R (Eds.); Plant Nutrient Management in Hawaii's Soils., Approaches for Tropical and Subtropical Agriculture, College of Tropical Agriculture and Human Resources, University of Hawaii at Manoa, Honolulu p. 31-55.

\section{Your next submission with Juniper Publishers will reach you the below assets}

- Quality Editorial service

- Swift Peer Review

- Reprints availability

- E-prints Service

- Manuscript Podcast for convenient understanding

- Global attainment for your research

- Manuscript accessibility in different formats (Pdf, E-pub, Full Text, Audio)

- Unceasing customer service

Track the below URL for one-step submission https://juniperpublishers.com/online-submission.php 